\title{
Colonialism and religion: colonial knowledge productions on Sri Pada as 'Adam's Peak'
}

\author{
Premakumara de Silva* \\ Department of Sociology, Faculty of Arts, University of Colombo, Colombo.
}

\begin{abstract}
This paper is directed to discuss the 'effective'aspect of colonial knowledge in the discursive constructions of one of the popular pilgrimage sites, Sri Pada in Sri Lanka. What the author explores here is how different authoritative discourses emerge about Sri Pada from the different colonial powers: Portuguese (1505-1687), Dutch (1687-1896) and British (18961948). Authoritative discourse on the 'colonised' was largely produced through the agents of the colonial governments, military personnel, Christian missionaries, philologists and administrators. In this regard, Sri Pada, or Adam's Peak as it was called by colonial powers, was not exceptional. These forms of knowledge production change with changes in the practices of colonialism. In this respect, this paper investigates what gets identified and counted by colonial authorised knowledge as 'Adam's Peak'. Such an investigation is not new to anthropology and the human sciences in general. A large body of knowledge has been produced in the last two decades to unpack 'a particular construction of colonial knowledge' (Pels, 1997). However, a limitation in such an analysis can be seen, because most of the 'decolonising projects' in South Asia (India and Sri Lanka) have located their fields of work and expertise in the $19^{\text {th }}$ and $20^{\text {th }}$ centuries to unpack 'British colonial knowledge production' and they have paid scanty attention to 'pre-British knowledge production'; for example, as far as India and Sri Lanka are concerned, the Portuguese and the Dutch 'colonial knowledge productions'. A reasonably comprehensive understanding of culture, religion and history of the various sub-continental regions in the early $18^{\text {th }}$ century and before is a prerequisite for the understanding of the transformations which the British instituted.
\end{abstract}

Keywords: Religion, colonialism, knowledge production

\section{INTRODUCTION}

"Colonial knowledge was frequently based on misunderstandings that led to an uneasy relationship between knowledge and power. It was often the uneasiness of this relationship that made colonial knowledge, in the end, so effective." (Dirks, 1992)

This paper discusses colonial knowledge as found in the discursive constructions of one of the popular pilgrimage sites, Sri Pada ${ }^{1}$ in Sri Lanka. The research explores how different authoritative discourses emerge about Sri Pada from three different colonial powers. As one is aware authoritative discourse on the 'colonised' was largely produced through the agents of colonial governments, military personnel, Christian missionaries, philologists, and administrators. In this regard, Adam's Peak as it was called by colonial powers, was not exceptional. These forms of knowledge production change with changes in the practices of colonialism. This paper, investigates what gets identified and counted by colonial authorised knowledges as 'Adam's Peak'.

Such an investigation is not new to anthropology and the human sciences at large. In the last two decades, a large body of knowledge has been produced to unpack 'a particular construction of colonial knowledge' (Pels, 1997). This line of research has been an attractive path for many South Asian scholars, especially, on India (Guha,

1 The orientalist knowledge production on Adam's Peak was not only confined to its socio-cultural and the historical formations but also similar attention was paid to 'understand' its botanical and physical worlds as well.

2 Siri- Pada is a popular usage among Sinhala Buddhist pilgrims; Sripadasthana (the temple of the sacred footprint) is the modern official usage; Sumana-kuta /Samanta-kuta (the peak of the god Saman) Samonola and Samanala (the Mountain of the Butterflies) are found in Pali and Sinhala scholarly writings and popular literature. Adam's Peak is widely used in european languages. 
1982, 1997; Cohn, 1985, 1996; Inden, 1990; Pandey, 1990; Dirks, 1992; Chatterjee, 1993; Chakrabarty, 2002) and on Sri Lanka (Spencer, 1990a \& b; Rogers, 1994; Scott, 1994b; Jeganathan \& Ismail, 1995; Roberts, 2001 \& 2003; Abeysekara, 2002). Something of the general significance of the emergence of anthropology of colonialism can be captured in the words of Cohn $(1985,1996)$ who has argued in the mid-1980's that "the conquest of India was a conquest of knowledge". Cohn's formulation is helpful to the understanding of Sri Lanka and other 'colonised' societies too. However, there is a limitation in such an analysis, because most of the 'decolonising projects' in South Asia (India and Sri Lanka) have located their fields of work and expertise in the $19^{\text {th }}$ and $20^{\text {th }}$ centuries to unpack 'British colonial knowledge production' and they have paid scanty attention to 'pre-British knowledge production.' A reasonably comprehensive understanding of culture, religion and history of early modern South Asia is a prerequisite for the understanding of the transformations which the British instituted ${ }^{3}$. Therefore, first 'knowledge productions' by Portuguese and Dutch on Sri Pada as 'Adam's Peak' need to be discussed.

\section{PORTUGUESE AND DUTCH DISCOURSES ON SRI PADA}

In the $16^{\text {th }}, 17^{\text {th }}$ and $18^{\text {th }}$ centuries Sri Pada belonged in the south-west geo-political border territory of the Kandyan kingdom, in other words, in the region of Sabaragamuva, where Kandyan control was through the administrative jurisdiction of the officer known as disave (provincial ruler). However, it was easily accessed from the adjacent coastal regions occupied by the Portuguese and Dutch. Hence, Sabaragamuva was sandwiched between the maritime regions and the up country hill regions. In this regard, Sabaragamuva was not fully controlled by either the Kandyan kings or the new conquerors of the maritime provinces. Interestingly, during this time, Sri Pada temple was mostly controlled by Hindu priests known as andiyas. While economic considerations were central to both the Portuguese and Dutch colonial projects in the island, despite their mercantilist domination in the maritime provinces, they also sought to convert the colonised to their respective religions, namely Catholicism and Protestant Christianity. According to C.R.de Silva (as cited in Roberts, 1989) there may have been about 100,000 to 175,000 Catholics in the south western maritime provinces by the early seventeenth century, which is about one-third of the population. However, according to Kuruppu (as cited in Stirrat, 1992), by 1911 there were almost 340,000 Catholics in the country. As a basis for economic and Catholic expansionism to the interior of the island, the Portuguese military attacked Sabaragamuva in 1599 and captured a considerable part of the region. In this attack, they destroyed the main shrine of the god Saman in Ratnapura, the guardian deity of Sri Pada and constructed a Catholic church and a garrison on this sacred Buddhist site (Skeen, 1870: Bell, 1916 ). The claiming of Sri Pada as 'Adam's footprint' first enters the European discourses as a result of the Portuguese expansionism of Catholic religion in the Island ${ }^{5}$. This shell should be explored through the accounts of Catholic missionary chroniclers of the Portuguese colonial power.

\section{ACCOUNTS OF CATHOLIC MISSIONARY CHRONICLERS}

Most of the chroniclers who are focused here visited the island as a vital part of the Portuguese colonial project in the regions, which needed the production of detailed accounts of the island, its people and the failures of governing them. These accounts were originally published in Portuguese and later edited and translated into English and some parts into the local languages too. For this discussion, the researcher shall draw on the English translations of de Queyroz (1930), Joao Ribeiro (1948) and Diego de Couto (1909) and Robert Knox's An historical relation of the island Ceylon written much later. de Queyroz (1930) wrote his account to explain as to why the Portuguese failed to establish a Catholic stronghold in Sri Lanka ${ }^{6}$. The most visible fixation in

3 A lively debate has sparked over the nature of 'colonial knowledge' that enabled European colonisers to achieve domination over their colonised subjects in South Asia and even beyond. As a result of this debate, two opposing approaches on the production of colonial knowledge have emerged; one sees colonialism introduced a profound epistemic disjuncture or rupture in the historical fabric of the society subjected to colonialism. Hence, there can be no significant continuities across the production of colonial knowledge (Inden, 1986 \& 1990; Cohn, 1996; Dirks 1992 \& 2001; Chatterjee, 1993). The other approach is largely conceived as revisionist critique of this post-colonialist view and it sees continuities between the late pre-colonial and early colonial periods (Bayly, 1998 \& 1999; Peabody 2001; Roberts, 2001 \& 2003; Rogers, 2004).

4 However, Rajasinghe II of Kandy rebuilt this shrine in 1658.

5 However, the Portuguese Catholic missionaries were not at all inclined to believe in the impression as being that of the foot-print of Adam; some attributing it to St. Thomas and others to the Eunuch of Candace, Queen of Ethiopia (Skeen, 1870).

6 de Queyroz was born in Portugal in 1617 C.E. He became a novice with the Jesuits in Coimbra in 1631 and began missionary work in South India in 1635. Between 1677-1680 he became the head of the Jesuits in India. But he never visited Sri Lanka and his production of knowledge on the island was mostly dependent on documentary material and stories narrated by other missionaries and travellers. His work was translated into English by a Sri Lankan scholar Father S.G. Perera in 1930. 
de Queyroz's (1930), as well as in Ribeyro's (1948) early $17^{\text {th }}$ century colonial accounts, is to homogeneously categorise pilgrims as 'heathens', and the relic that they venerated as a work of 'heathenish hypocrite'. This is to give the impression that non-Christian beliefs and popular practices are based on 'false' assumptions. Such a stance, according to Malalgoda (1997), had precedents in a Europe that was in the throes of Reformation and Counter-Reformation. In their view, resemblances between their own religion and those of others were not simply deceptive.

"but the Devil, who had tremendous importance in Christian thinking at the time....such resemblances themselves were proof that other religions were diabolical counterfeits." (Malalgoda, 1997)

However, though these missionary chroniclers disparaged the non-Christian religions as 'heathenish' or 'false', at the same time, they were compelled to find ways in which to introduce European 'true' religious beliefs and practices to the 'heathens' and convert them. The religious conversion was reinforced mainly by the use of force, which became manifest in attacks on the temporalities of the other religions: the destruction of temples and their contents, and the expulsion of their residents and custodians (Abeyasinghe, 1966) and through imposing Christian beliefs and practices on the 'native' by the strategy of religious 'conversion'. This combination of temporal and spiritual conquest, can also be seen in the other chroniclers' accounts. For example, Knox (1681) confirmed that by the mid seventeenth century 'the European nations' had claimed the sacred footprint site as that of Adam:

"On the South side of CONDE UDA [kanda uda] is a Hill, supposed to be the highest on this island, called in the CHINGULAY [Sinhalese], 'HAMALELL [samanala]; but by the Portuguese ${ }^{7}$ and the European Nations, Adam's Peak. It is sharp like a sugar-loaf, and on the top a flat stone with the print of a foot like a man on it, but far bigger, being about two foot long. The people of this land count it meritorious to go and worship this impressions; and generally about their New year, which is in March, they, men, women and children, go up, this vast and high mountain to worship..."

Indeed, de Couto9, another Portuguese missionary chronicler claims that the sacred footprint at Sri Pada mountain was not of Adam but of a Catholic Saint, Thomas, who also had impressed the mark of his knees upon a stone in a quarry at Colombo (Skeen, 1870). However, he went on to say that the Portuguese gave the footprint, the name of Adam's Peak [Pico Adam] and "[but] Sinhalese name it 'DEWA GORATA' [deviyange rata $^{10}$ ]". This claim of de Couto was later put differently by a British military officer, Percival (as cited in Skeen, 1870), in his Account of the Island of Ceylon in 1803:

"The Roman Catholic priests have also taken advantage of the 'current superstitions' to forward the propagation of their own tenets and a chapel which they have erected on the mountain is yearly frequented by vast numbers of black Christians of the Portuguese and Malabar race."

Similarly, well-known British administrator, James Emerson Tennent (1859) points out the conflicting claim of 'Portuguese authorities' that the sacred footprint was that of St. Thomas and of the Eunuch of Candace, Queen of Ethiopia. Whatever different claims that existed during this period, it is clear that by the seventeenth century, the belief of Sri Pada as 'Christian Adam' was an established one. This is further evident in the work of Paolo da Trinidade ${ }^{11}$ (as cited in Peiris, 1972), a Portuguese, Catholic missionary chronicler who wrote briefly but enthusiastically about Sri Pada in his voluminous chronicle of The Spiritual Conquest of The East:

Knox (1681) says that the Portuguese call the Adam's peak as 'Pico-Adam'.

8 Robert Knox, a British marine captain who was imprisoned with his crew for a period of almost 20 years under the Rajasingha II (1635-1687) in the Kandyan royal court. At that time maritime provinces were under the Portuguese or Dutch control. Knox wrote his account after his escape and published it as the book title 'An historical relation of the island Ceylon' under the publisher of the Royal Society at the Robe and Crown in St. Paul's Church Yard in 1681.

9 Diego de Couto served the Portuguese Crown as soldier, chief keeper of the records in Goa and official chronicler of India. He wrote the history of the Portuguese eastern empire from 1526. His Decadas da Asia was written and published intermittently from 1602 onwards. The material on Ceylon by Couto is in his 'fifth Decada' (as cited in Arasaratnam, 1978).

${ }^{10}$ Literally meaning is 'God's country'; but this usage usually referred to the 'territory of the deity Saman'.

11 He was born in 1571 and died in 1651 at age of eighty; was a well known Franciscan priest who wrote extensively on Catholicism in the eastern part of the world and his work relating to Sri Lanka was translated and edited by Edmund Peiris and F.A. Meersman under the title Chapters on The Introduction of Christianity to Ceylon in 1972. 
"There are many notable things found in this island, of which we could make a long description, but we mention only some, both to avoid prolixity and because they do not appertain to our history. And the chief of them is the Peak that they call of Adam. Which is a very lofty mountain at a distance of a day's march from our fort of Safregam [Sabaragamuva] to the side of the East and twenty leagues from the coast.... they say it is the footprint of BUDUM, who is one of their gods and whom they say was a giant, eighteen carpenter's "covados" tall. Our people [Christians] call it the peak of Adam and say the footprint is his, but its proper name is SARMANALA [samanala]..."

These assertions provide evidence about how the Portuguese constructed a Christian connotation(s) of the sacred footprint and legitimatised them through the religious practices of newly converted Christian pilgrims at the site of 'Adam's' footprint. Interestingly, there is no historical record that the temple was controlled by Catholic missionaries even when Portuguese power was at its height. However, Catholic missionaries did not fail to construct Sri Pada as the site of Christian mythologies centred on sacred figures such as Adam, St. Thomas, and Queen of Ethiopia.

The Portuguese lost their hegemonic power over the maritime provinces in the island to Dutch East India Company in 1656 but the construction of the mythohistorical Adam around Sri Pada continued in more complex ways under the Dutch. In 1689, the Ceylon Dutch Consistory assessed the religious situation in the island by letter to the United East India Company. A part of it shows how the Dutch thought about 'natives', specifically Sinhalese religious practices:

"The Portuguese, the late occupants of the country, destroyed the dagabas and heathen edifices; and did not tolerate the public exercises of devil-worship. We also issued in 1682 strict placates against all such ceremonies, and inflicted heavy penalties. Heathenism, which for the last years had lost its influences to a great extent, so that many left it for Christianity..." (as cited in Walters, 1996)
The Dutch (Protestant) missionaries who arrived after the Roman Catholic ones, Christianity was no less important. Baldaeus (1960), in the preface dated 15 August 1671 to his book on South India and Sri Lanka, defined 'the noble object' of missionary activity as "the conversion of souls that were caught in the snares of Satan." (as cited in Malalgoda, 1997)

Under such 'noble object', the Dutch took Sri Pada affairs seriously and in March 1672 a group of Dutch soldiers were sent to Sri Pada to examine the footprint ${ }^{12}$. But the Dutch often confused Adam's Peak with other rock (hill) temples in the Island, particularly the ancient rock temple at Mulkirigala in the Southern district of Hambantota. This rock temple was identified by the Dutch themselves as 'Adam's Berg'. Whatever might have been the motive, which impelled the Dutch to call this rock temple as Adam's Berg, it had confused the Dutch chroniclers themselves after identifying the 'real' Adam's Peak ${ }^{13}$. However, the confusion seems to remain unsolved even in the main accounts of the Dutch missionary chroniclers, who had produced authoritative 'knowledge' on Sri Pada.

In this regard, the accounts of Francois Valentyn and Philip Baldaeus are worth examining at least briefly ${ }^{14}$. Both chroniclers wished to construct a 'concise account' of Adam's Peak but ended up with serious confusion. However, the remarkable feature of their narratavisation of Sri Pada is the use of evangelical language familiar to the missionary and their audiences. In fact, Valentyn and Baldaeus have little problem deciding in favour of the historical precedence of Christianity over Buddhism. For Valentyn, "Buddha is a disciple of Apostle Thomas."

This indicates that the Dutch missionary knew little, both about the historical personage of the Gautama Buddha and his doctrines, even the places of worship for him. What is clear in both Portuguese and the Dutch chroniclers' accounts on Sri Pada in particular and other religions in general is that they were full of errors, misunderstandings and ignorance of the 'native' beliefs and practices. In this respect, Sri Pada was recognised as a place of Christian worship while making the clear distinction between true religion and false religion. Without such a distinction there could be no justification

12 Skeen, 1870: 70

13 R. L. Brohier shows some references to this rock temple in Dutch times (Journal of the Dutch Burgher Union of Ceylon Vol.xx, July 1930, $1-11 p)$.

14 Valentyn was born in 1666 and in 1684 he qualified as a minister of the Dutch Reformed Church. He served as a historian (observer and record keeper) to the East India Company and a minister to the Dutch Reformed Church in India for eleven years. He returned to Holland in 1695 However, in 1705 he was again appointed to the Reformed Church in India until April 1714 and he died on 6th August 1727. (Arsaratnam, 1978). Philip Baldaeus had served in Sri Lanka from 1656 to 1665 as a minister of the Dutch Reformed Church. 
for the missionary enterprise under neither the Portuguese nor the Dutch.

\section{BRITISH 'ORIENTALIST' DISCOURSES ON SRI PADA}

In the nineteenth century, British scholarship on Sri Lankan religions, particularly Buddhism and Hinduism, further constructed new fields of study to understand these religions as a western object. Hence, colonial discursive knowledge productions on these religions were presented by the 'orientalists', such as British military officers, administrators and Christian missionaries, who constantly encountered interpretative difficulties. But the objectification of those religions was considerably more figurative than literal and this took place purely under verbal encounters, which were widely used under the Portuguese and the Dutch 'objectification' of those religions.

Orientalist knowledge productions on Sri Lankan religions, however, are best explained through a specific religious pilgrimage site, because knowledge about Sri Pada was itself part of the larger colonial production of knowledge on doctrines of Sri Lankan religions and their practices. The concern with British productions of knowledge on Sri Pada is not unvarying, because, British colonialism itself constituted a changing practice of power and therefore, produced and organised historically varying conditions and effects of knowledge. The earliest orientalist discourses, which appeared in the first quarter of the nineteenth century were different to the late nineteenth century accounts and likewise the early twentieth century.

On the morning of 16 February 1796, the British took possession of the Dutch East India Company's garrison in Colombo on the southwest coast of Ceylon. It marked the final capitulation by the Dutch of the maritime provinces of the island, which they themselves had captured from the Portuguese, a century and a half ago, in 1656. After nearly two decades in the maritime provinces, in 1815 the British became the first European power to establish control over the entire island. The initial annexation of the Kandyan Kingdom was negotiated, but soon after resistance came from a major indigenous uprising in 1817-1818, which met a strong military response from the British ${ }^{15}$. Maintaining control over the newly acquired 'interior', or Kandyan hill territory was the vital project of the British military agenda at the time. In opposition to unknown 'interior' lands, much of the coastal lands were well 'known' and 'ordered' by Portuguese and Dutch colonial projects of conquest and rule that began in the sixteenth century. For this vital project, the military officials were required to be competent in many fields, such as, the judicial and the executive and were also expected to construct a sociological and historical knowledge of the colonised subjects of the 'interior' regions. As such, the published accounts of indigenous history and sociology of the early British period initiated colonial knowledge about 'Ceylon'. Undoubtedly, the early knowledge productions on the 'colonised' largely came through the result of the 'colonisers' military project. Surprisingly, such knowledge remains so far, even uncritically, unused in the vastly growing 'postcolonial scholarship on Sri Lanka'.

\section{KNOWLEDGE PRODUCTION OF MILITARY OFFICERS}

As a part of the territorial exploration project in newly conquered land, several military groups were sent to Sri Pada area to report whether the situation of this 'wilderness and mountainous territory' still might be a safe place for 'enemies'. One of the main purposes of such military exercise might have been to search what had really been going on at Sri Pada temple under the name of 'pilgrimage'. For the military to undertake those tasks, there was a considerable number of military parties exploring the 'wilderness' territory of Sri Pada through its Southern (Sabaragamuva) and Northern (Kandy) territorial ends. Most of the military officers who participated in this exploration project later published their accounts as part of the texts that they wrote themselves on 'colonised subject'. These 'colonial military literature' can be used to demonstrate the early British colonial knowledge productions on Sri Pada; more precisely 'Adam's Peak'16.

\footnotetext{
15 One incident which happened during this negotiation is worth mentioning here: In 1803, Prince Muttusami (brother-in-law of the late King Rajadhi Rajasinha), a would be British sponsored claimant to the throne of Kandy, was asked to cede a province of the Kandyan Kingdom in exchange for assistance. He refused to cede Sabaragamuva, because it brought substantial revenues and would lead to the loss of Sri Pada, "the sacrilegious cessation of which would bring down on him". Instead, the prince was willing to cede the province of Nuwarakalaviya (de Silva, 1953), where the 'sacred city of Anuradhapura', which became 'national heartland of Sinhala Buddhists' after the late nineteenth century, was situated.

16 There are substantial military literature that cited or described 'Adam's Peak'. But, for this analysis all that military literature in not used. Some of the excluded accounts are; Lieutenant Holman, R.N visited Sri Pada in 1830 and published his account Travel around the world in 1854 vol. iii; Colonel Walker of the $61^{\text {st }}$ Regiment and his wife visited in 1820 and their account was published in Hooker's Companion to the Botanical Magazine in 1835; Lieutenant De Butts published Rambles in Ceylon in 1841; An officer, late of the Ceylon Rifles published Ceylon: a general description of the island historical, physical, statistical vol. ii in 1876.
} 
The first exploration of this kind was started on $26^{\text {th }}$ April 1815, by a group of the first Ceylon Rifle Regiment of the newly established garrison at Batugedara in Ratnapura, led by Lieutenant Malcolm. The military party of Malcolm received local support from the village Headmen of Batugedara, Dolip Nillame. Lieutenant Malcolm's account is important for two reasons; it seems to be the first knowledge production on Sri Pada by a British military officer and importantly it also shows how the British began to 'understand' the natives' religion ${ }^{17}$.

"... The route winded with the Kalu Ganga, [lit. the black river] or Kaltura river, which about two miles from Batugedara... On the left bank, there are ruins of a Kandyan fort, erected during the late war to command the ford... leaving the Gillemalle rest-house, we immediately crossed the Malmelloe river and about half a mile further on, the Maskelle river. ... about four p.m we arrived at Palabadoolla, ten miles and eighteen chains from Batugedara. There is a considerable temple of Buddha, and a large rest-house for pilgrims... about two hundred pilgrims, of both sexes and of all castes and conditions, were here assembled, some on their way to, and others on their return from, the Peak. The dance was continued without intermission, to the sound of Tam-a-tams [drums] and other instruments of Singhalese music, until the pilgrims, who were about to ascend the mountain, began to prepare their lights; and at about eight p.m. they proceeded onwards in distinct parties.

The Head Priest [Palabaddala temple] whom I received every possible attention, tried all the persuasive rhetoric he could muster, to prevent me from proceeding further towards the Peak; assuring me, that 'no white man ever did and never could ascend the mountain' I soon convinced the benevolent OONANSE [the Buddhist priest] that I was not a white man to be dissuaded from the attempt through any dread of ulterior danger... having been well refreshed,... and left Palabadoola about eleven at night. After passing three small forts that had been thrown up during the war, we began to ascend the first mountain... and about five a.m. we breakfasted upon the rocks... Adam's Peak still towering far above our heads... the pilgrims in advance of my party were seen climbing up the precipice by the assistance of the iron chains which are fixed in the rock for that purpose... we reached the top between eight and nine a.m.. of the $27^{\text {th }}$ April... the area of the summit of the peak is 72 feet long and 54 broad, and is enclosed by a parapet wall five feet high; this has partly fallen down on the east side and remainder is sadly out of repair. In the middle of this area... is a mark of Adam's left foot, called Sri Pada by the Singhalese; but it requires a great deal of help from imagination to trace it out. This sacred footstep is covered over with a small building formed of the most durable wood, 12 feet long, 9 broad, and 4 and half to the tiles, with which it is surmounted. Upon the inside it is enclosed by a frame of copper fitted to its shape, and ornamented with numerous jewels set in four rows, but not of the best gems... for to me they looked very like glass.

We were not (I regret to say), provided with an 'Union Jack' but we fired three volley, to the great astonishment of the Buddhists, as a memorial to them that a British armed party had reached the summit, in spite of the prediction of the priest of Palabadoola... we reached Palabadoola about 4 p.m. and returned to my quarters at Batugedara the next morning..."

Shortly after Lieutenant Malcolm's exploration, another military officer explored the same route to Sri Pada and gave an account similar to Malcolm's but in different flavour $^{18}$. However, one particular military officer, Dr. John Davy's, account on Sri Pada is worth summarising here ${ }^{19}$. Davy published this account in 1821 under the title An account of the interior of Ceylon and its inhabitants with travels in that island, in which he wrote a chapter on 'Adam's Peak'. His exploration met with the task of 'scientific inquiries' on Sri Pada where he measured and testified the authenticity of the 'sacred footprint' and the temple structure. He also measured the height of the mountain and tested the temperature of the air and the water in several locations of the

17 His account appears in J.W. Bennett's (1843) Ceylon and its capabilities: an account of its natural resources, indigenous productions, and commercial facilities. Bennett filled several posts in the Southern Province. His services were terminated by the government in 1827 because of accusations against him concerning financial mismanagement (as cited in Harris, 1994 [2001]).

18 To read this account, see the appendix of Captain Anderson's Wanderer in Ceylon and Skeen (1870).

19 John Davy lived in Ceylon between 1817 and 1819. He was born in 1790, he studied medicine in Edinburgh and obtained an MD degree in 1814, after which he joined the army. His subsequent career saw service in other parts of the world and an impressive list of publications...(as cited in Harries, 1994). Also see more information about him on the John Davy Collection (GB0116) of Royal Institutions of GB or www.aim25.ac.uk. 
sacred mountain ${ }^{20}$. For these tasks he was equipped with a barometer and thermometer which were useful technologies for emerging 'scientific knowledge'about the natural world of 'Ceylon'.

Such 'rational' narrativisation of Sri Pada in the early phase of the British Empire was an outcome of its military project of the territorial 'explorative' exercise. Before these military exercises, Sri Pada was physically [through actual contact] unknown to the British colonial regime. But by 1830, Sri Pada was a well-known place for them. In the first military exercise, Sri Pada temple and its 'wilderness' southern territory was explored and cleared. The first conquest was also symbolised by the firing of three heavy gunshots in the temple premises. The gunfire also indicated that Sri Pada had come under British occupancy and authority. Similarly, through other military explorations the sacred region was further clarified, cleared and confirmed as an area free from a potential 'native' rebellion against the colonial regime.

Broadly speaking, most of the British military accounts, which appeared in early nineteenth century about Sri Pada, highlighted and inquired 'what were the pilgrims doing at the temple?' and 'what did the temple look like?' [the structure of Sri Pada temple]. For example, the 1819 exploration provided much detail on the size of the footprint and its genuineness, and the ritual practices of both the resident Buddhist monk and the pilgrims. Generally, these explorations had provided an authoritative knowledge on what Sri Pada 'looked like' or 'what could be observed at Sri Pada', but they were not interested in searching the 'history of Sri Pada' as their fellow officials would do later. In other words, these narratives provide 'a hegemonic discourse' on Sri Pada in the early phase of the authoritative knowledge production on the practices of the native religions. However, the constructed historiography of Sri Pada was not prominent in the early narratives. In fact, it became visible in much later works of the colonial historians, more precisely in the works of the colonial scholar/ administrator. These 'military accounts' provide us with a powerful marker of the particular historical moment in which a new discourse about Sri Pada in particular, religion in general, and the overall project of British colonial knowledge production on 'Ceylon' emerged.
The early formation of British colonial knowledge about Sri Pada was largely the work of British military officers in Ceylon in the nineteenth century. Knowledge about Sri Pada was itself part of the larger colonial production of knowledge regarding religion and observances of the natives. As Scott (1994b) reminds, British colonialism did not constitute an internally unvarying unity. It constituted a changing practice of power and therefore, produced and organised historically varying conditions and effects of knowledge. The absence of military accounts by the middle of the nineteenth century showed that scholars/administrators of British Ceylon had effectively supplanted them. Orientalism, in other words, became part of the Evengelical Christian technology of subjectification and colonial discipline.

\section{PRODUCTION OF 'SYSTEMATIC KNOWLEDGE' UNDER COLONIAL ADMINISTRATORS}

The authoritative historical knowledge about Sri Pada was produced after the mid-nineteenth century. Hence, one shall see how British colonial power in Ceylon systematically produced 'a discourse of Adam's peak', this time by eloquent scholars/administrators of British Ceylon. This discourse of Adam's Peak, however, is not a static one but was subject to change when the construction of colonial knowledge about history and sociology of the colonial subjects was emerging.

By the middle of the nineteenth century, economic considerations, rather than purely military ones, were dominant in the government of the British Ceylon. Administrative and military authority was now separated and organised and the mercantile capitalists and planters were important segments of the colonial bourgeoisie. As a productive outcome of this reordering project, the serious intellectual knowledge production about the colony was also institutionalised. This was after the formation of the Ceylon Branch of the Royal Asiatic Society in 1845, which was modelled on existing parent societies in London and Calcutta ${ }^{21}$. Most of the founding members came from diverse backgrounds and all segments of the newly emerged colonial bourgeoisie. However, this newly-formed institution was at the beginning dominated by the evangelical Christian missionary scholars and scholars from the colonial

20 He notes that "the extraordinary heights assigned by some old authors to Adam's Peak of twelve and fifteen thousand feet, are certainly erroneous. According to a rough trigonometrical measurement of the late Lieut. Col. Willerman, the Peak does not exceed 7,000 feet and thus confirming [my] barometrical estimate." (1983) However, 'accurate' figure was latter found by a well developed scientific inquiry of the late British Ceylon as 7360 feet.

21 The Calcutta or Bengal Asiatic Society was founded by William Jones in 1784 where early orientalists' knowledge of Ceylon was narrated and constructed. Subsequently, this 'knowledge' appeared in the highly influential journal of the Society, Asiatic Researches. 
civil service 'scholar/administrator' in British Ceylon ${ }^{22}$. The determinant aims of this intellectual body were to "collect scattered rays of information possessed by different individuals" and to "encourage a literary and scientific spirit...in the island" (as cited in Jeganathan, 1995). Interestingly, many of the major knowledge producers on Sri Pada were active members of this newly established intellectual circle. This is not to say that there were not other forms of knowledge production on Sri Pada in British Ceylon ${ }^{23}$. Given the nature of the subject matter, the researcher's intention is to show how British colonial power in Ceylon produced a discourse around 'Adam's Peak'. Some major works on 'Adam's Peak' by one of the active members of the RAS Ceylon branch will be explored for this purpose.

Sir James Emerson Tennent, the Colonial Secretary at the time the RAS Colombo branch was founded, was Vice-Patron ${ }^{24}$. Tennent (1859) included a concise 'history' of Adam's Peak with his narrative focussed on two points. Firstly, he encountered native religious practices, particularly around Sri Pada and as other orientalists had, he labelled them 'superstitious'. Secondly, the account attempted to clear the name of Adam that had surrounded the claim of the religions of Muslims and the Catholic pilgrims. In other words, his attempt was to make a clear distinction between Christianity and the practices of 'exotic' religions. This he demonstrated through an attempt to separate evangelical 'Christian Adam' from the 'Islamic Adam' and the 'Catholic Adam'. His attempt clearly shows how objectification adopted different attitudes toward various religious practices. The substance of Tennent's account exemplified this colonial attitude towards 'exotic' religions ${ }^{25}$.

However, Tennent's attempt was not the final study on Sri Pada in the 'regime of positivist historiographic truth'26. Although, the complete authoritative 'historiography' on Adam's Peak was constructed in 1870 , by another member of the RAS, William Skeen who wrote nearly four hundred pages long text on the subject. In fact, Tennent's concise history on Adam's Peak unquestionably had affected production of an authoritative discourse on Adam's Peak. Hence, before examining the work of William Skeen, it is important to discuss the work of Sir Emerson Tennent.

Tennent produced his narrative on Adam's Peak as a part of the description of his 'official' journey from the south coastal town, Galle, to the capital city of Colombo. The major component of that journey was to visit Adam's Peak in the 'interior' region of Sabaragamuva. He tells what he 'observed' during this journey. At the beginning of his narrative he reported that the 'difficulty of the journey' and later how he enjoyed splendid surrounding of the Adam's Peak. But his deliberate intention was to construct a teleological narrative on Adam's Peak.

For such history, as a point of departure, he temporally accepted that the name of the sacred mountain, 'Adam's Peak', was initially derived from the Portuguese word "Pico de Adam". Then he constructed his positivist historical account about Adam's Peak (1859). For him, in the first stage, Sri Pada was a site where the Vadda worshiped 'for ages' (the age of worship of natural object).

"The veneration with which this majestic mountain has been regarded for ages, took its rise in all probability amongst the aborigines of Ceylon, whom the sublimates of nature, awaking the instinct of worship, impelled to do homage to the mountains and the sun." (ibid.)

22 As an example, the Wesleyan missionary scholar of Buddhism, Daniel J. Gogerly was the first chairman of the RAS. Gogerly was born in 1792 and arrived in Sri Lanka in 1818 to supervise printing activities. He entered the ordained ministry in 1823 and served for 40 years in Sri Lanka until his death in 1862 (Harris,1994). Gogerly's scholarly efforts were not motivated by a sympathetic attitude towards Buddhist teachings. Rather, he learned Buddhism and Pali in order to equip himself and his fellow missionaries with additional evidence for demonstrating the superiority of Christian teaching (Malalgoda, 1976).

23 For example: by the late nineteenth century, popular narratives on Sri Pada began to appear in print media. There are voluminous print pamphlets or 'folk literature' or 'subaltern pilgrims literature', simply written in 'popular language rather than a classical literary style' poetic or story forms by non-elitist composers such as leaders of pilgrims groups (nade guru), non-scholarly monk and other ordinary laity (upasaka) but in some literature authors are unknown. These can be accessed at; Sinhalese pamphlets collection of Colombo National Museum (SP104-A-Z), H. Nevill (1956) Sinhala Kavi (vol..I,II and III). These kinds of popular literature have been edited, reprinted and widely distributed. Some of them are still available during the pilgrimage season.

24 Tennent (1804-1869) lived in Sri Lanka between 1845 to 1850 as the colonial secretary. In 1832 he entered parliament in Britain as member for Belfast and in 1841 be became secretary to the India Board and just before he came to Sri Lanka he was knighted. Sir Tennent was the third son of a wealthy merchant of Belfast in Ireland.

25 He also wrote another book titled Christianity in Ceylon London: John Murray, 1850.

26 According to Focauldian fomulation, "regime[s] of truth ensemble of rules according to which the true and the false are separated and the specific effects of power attached to the true" (1984:73). In other words, a 'regime of truth' orders and organises knowledge, allowing for truth claims to be made. 
In the second stage,

"the religious interest became concentrated on a single spot to commemorate 'some individual' identified with the national faith and thus the hollow in the lofty rock that crowns the summit was said by the Brahmans to be the footstep of Siva, by the Buddhists of Buddha, by the Chinese of Foe, by the Gnostics of Ieu, by the Mahometans of Adam, while the Portuguese authorities were divided between the conflicting claims of St. Thomas, and the Eunuch of Candace, Queen of Ethiopia."(Tennent, 1859 )

This was how he formed or arranged lineal or chronological order in what he called 'phases'. Then he wanted to examine 'accuracy' of the origins of each religious faith ('superstition') related to 'Adam's Peak'. For him that "can be traced with curious accuracy through its successive transmitters" (Tennent, 1859). Here, Tennent was more keenly targetting the origins of religious practices of the Catholics and the Muslims but not of the Buddhists and the Hindus. This was because the Catholic and the Muslim religious groups traced their faith to Adam and legitimised their religious practices by venerating the sacred footprint as being of 'Adam'. Regarding the Catholic case, Tennent's attempt was to show that Catholics were not in favour of one particular faith but they had conflicting beliefs in many faiths ${ }^{27}$. By quoting the Portuguese missionary chronicler, de Couto, Tennent (1859) emphasises that Roman Catholics were in favour of St. Thomas than of Adam: "de Couto pleads more earnestly in favour of St. Thomas". Tennent lent the weight of de Couto's authority on this statement and was convinced that Adam's Peak was imprinted with the foot of St. Thomas, not with the foot of Adam. What really provoked Tennent's account was that the "evangelical mind" (to borrow a phrase from Stokes, 1959) rejected or ridiculed the prevailing practice of Christianity at Sri Pada.

Having clarified that, Tennent (1859) went on to confront the Islamic belief that the footprint was Adam's. He was puzzled by the origin of the Muslim practices at Adam's Peak under the primal man of Christian faith. He surprisingly wrote "Strange to say, the origin of the Mahometan tradition as to its being the footstep of Adam". For him, this shocking historical ambiguity would be only solved by referring to a Christian source. Hence, he brought a fourth-century Christian manuscript, which contains a section called "Faithful Wisdom", and confirmed by referring it as "the earliest recorded mention of the sacred footprint of Adam's. Having identified the historical origin of Adam's sacred footprint, Tennent was keen to explain how this Christian veneration entered the Muslim faith. Tennent blamed Gnostics because, for him, they "corrupted Christianity" by communicating the mystical veneration of Adam to Muslims. Then Tennent made an attempt to clarify how the Muslim veneration of Adam get connected with the sacred footprint in Ceylon. In the religious code of Mahomet, Adam was "the first of God's vice-regents upon earth" but the Koran makes no mention of the exact place where Adam has fallen from Heaven;

"the age of Mahomet, his followers had not adopted Ceylon as the locality of the sacred footstep; but when the Arab seamen returning from India, brought home accounts of the mysterious relic on the summit [in Ceylon]." (Tennent, 1859)

Hence originated the claim of the sacred footstep as 'Adam'. Tennent (1859) concluded, “it was not till the tenth century that Ceylon became the established resort of Mahometan pilgrims". In this regard, Tennent clarified the origins of the Christian veneration of the sacred footprint of Adam. Christian veneration was older, more original or more 'real' than the Muslim veneration of Adam's footprint. The construction of evangelical Christian supremacy over the other religions, particularly non-Christian (Buddhism and Hinduism) religions, was a major part of the process of the production of colonial knowledge in British Ceylon.

As Scott (1994a) points out,

"Victorian English Christians in the midnineteenth century Ceylon were more discrepant and unaccountable with the observable popular practices of the natives than the avowedly lofty and metaphysical precepts of the religious texts."

Scott's point can be demonstrated through Tennent's account where he categorically labelled the religious practices at the sacred footprint as 'superstition'. Not surprisingly, this was the general categorical understanding of the complex native religious practices by oriental scholarship when producing the authoritative knowledge of native's practices. Tennent's (1859) disrespectfully noted that,

"the indentation in the rock is a natural hollow artificially enlarged, exhibiting the rude outline of a foot about five feet long, and of proportionate

27 Farther S.G. Perera (1919) noted that "Tennent exaggerated the fraction of truth contained in it." 
breadth; but it is a test of credulity, too gross even for fanaticism to believe that the footstep is either human or divine."

Tennent produced a 'scientific' site plan of the temple, which was the first site plan of the temple that had been produced in 1841. The temple area was mapped out and documented (its length and width as 64 feet by 45 feet) and also the sacred objects and their locations of the temple were identified, marked and recorded (Tennent, 1859).

After testing the authenticity of the sacred footprint and identifying the temple site 'scientifically', Tennent (1859) described the ritual practices at the temple as follows;

"it (ritual) consists of offerings, chiefly flowers of the rhododendron, presented with genuflexions, invocations and shouts of Saadoo! (Amen!). The ceremony concludes by the striking of an ancient bell and a draught from the sacred spring, which runs within a few feet of the summit ${ }^{28}$."

The model of Tennent's investigation of the historical and the religious practices regarding Sri Pada was the basis for the later knowledge producers on this subject. His work was quoted extensively in Europe and Sri Lanka, particularly in the growing 'historical' knowledge in the nineteenth century about the island. Hence, Tennent provides an authoritative framework in the production of a hegemonic discourse on Adam's Peak in nineteenth century British Ceylon.

\section{TEXTUALISATION OF ADAM'S PEAK}

The construction of the history of Adam's Peak within this framework is more elaborately represented in the work of William Skeen, who was an active member of the Colombo branch of the Royal Asiatic Society and wrote the most authoritative and comprehensive account on 'Adam's Peak', titled Adam's Peak: legendary traditional and historic notices of the Samanala and SriPada with a descriptive account of the pilgrims' route from Colombo to the sacred foot-print, published in Ceylon in $1870^{29}$. His text consists of ten long descriptive chapters but eight of them narrate his journey from the capital city of Colombo to Adam's Peak and the way back to Colombo.
However, his intention in these 'excursions' was clear;

"There is perhaps no mountain in the world of which so widespread a knowledge exists, as Adam's Peak. Almost every traveller to, or writer on, India and the East, has alluded to, noticed, or more or less described it. But considering the sanctity in which it is held by Buddhists, Hindus, and Mohammadans; the numerous legends and traditions connected with it; and the immense number of pilgrims who annually visit the alleged foot-print upon its summit; it is surprising how little has been recorded by any one author, and what wide and glaring discrepancies appear in the different accounts respecting it which have from time to time been given to world." (Skeen, 1870)

Without doubt Skeen (1870) wanted to produce a 'true' final account on Adam's Peak because the knowledge produced at that point was full of 'discrepancies', hence for him knowledge has to be produced by one author in the 'regime of truth'. In other words, for Skeen it was difficult to find accounts on Adam's Peak that could be treated as 'truth'. Hence finally, 'the truth of the Adam's Peak' must be produced or organised or ordered. He wrote about this task as;
"My principle endeavour has been, to bring into one common focus all attainable information; and to describe more fully than has hitherto been done." (Skeen, 1870)

Not surprisingly, like other Orientalists, Skeen's attempt was to construct an authoritative knowledge on 'every' aspect of the Adam's Peak, which is lucidly expressed in the title of his text. No doubt, as Skeen says,

"I trust that the work now published may be deemed worthy of a place alongside those of others whose pens in times past have illustrated the history and antiquities of Ceylon." (Skeen, 1870)

Both Tennent and Skeen narrations on Adam's Peak further legitimate as the 'true' hegemonic accounts on the subject by being cited not only in the late nineteenth century accounts of Adam's Peak but also in the twentieth century scholarly writings. For example, T.W. Rhys Davids, founder of the London Pali Text Society,

\footnotetext{
28 The author has not come across such a place or ritual oriented to the sacred spring.

29 This text was published to mark the royal visit of the Duke of Edinburgh to the British Ceylon and it was also dedicated to him. The text was first published by W.L.H Skeen \& Co in Colombo, whereas it was republished in 1997 by the Asian Educational Services in New Delhi.
} 
was almost entirely dependent on Tennent and Skeen's narrations when he introduced Adam's Peak in his work Encyclopaedia of Religion and Ethics in 1925. It shows how their work immensely influenced the production of knowledge on Adam's Peak. Indeed a major element of both Tennent and Skeen's descriptive projects was the identification of Adam's Peak as an important site for British colonial regime.

The orientalists' attempt to produce 'scientific rational knowledge' on Adam's Peak cannot be understood in isolation from their attitudes towards religious practices of the 'natives'. The Portuguese discourse on Adam's Peak denied rather than reject the existing religious practices of Buddhists, Hindus and Muslims as 'heathens' or 'idolatry' and this rejection made use of them to assimilate more or precisely 'convert' a group of 'natives' into Catholicism through means of 'power' or introducing new Catholic 'connotations' to the sacred sites. However, the Dutch and British discourses (particularly the nineteenth century British orientalists, Christian missionaries and colonial administrators) objectified the practices of the native's religions but adopted different attitudes toward them while treating them as 'exotic' religions. This was partly because orientalists had seen or defined existing religious beliefs and practices as 'corrupt' or 'superstition', hence for them 'corrupt' practices were incommensurable with the 'truth' of Christianity or more correctly, normative Victorian ideas and values of the British Empire. In the case of Adam's Peak, such ambivalence is readily apparent and further demonstrates that the orientalists rejected or rather, criticised or ridiculed the religious practices at Sri Pada as 'superstition'30.

Such discursive criticism did not adversely affect the existing diverse religious cohabitants at Sri Pada in particular, or whole pilgrimage practices in the country in general. This religious cohabitancy is clearly demonstrated in some of the late colonial knowledge production that the author would like to label as 'tolerance discourse'. Such tolerance discourse is, for example, clearly visible in a book written by colonial writer, Still, in 1930. Under a separate chapter, titled 'A Holy Mountain', he writes:

"Among the pilgrims I have seen people of half a dozen races, with as many languages, and at least four distinct religions beside many sects... the tolerance of the pilgrims seemed a thing that might well have been studied by Western ecclesiastics with honour and amazement, perhaps even in shame. I mentioned this tolerance once to a bishop, and was told it was a sign of weakness of faith; persecution. I suppose, is a sign of strength..."

Similarly, Sir Vivian Majendie who visited Sri Pada on January 1, 1896 reported that,

"In the height of the pilgrim season the scene is most extraordinary -- men, women, old and young, some almost decrepit, some who actually die on the way and many who have to be pulled or carried up -- people from all over India, from China, from Japan, from Burmah, from Siam, from Ceylon, from Africa - from all the seats of the three great religions...'(A Gazetteer: xi)

Even Tennent (1859) reports that,

"the Buddhists are the guardians of the Sripada, around this object of common adoration the devotees of all races meet, not in furious contention like the Latins and Greeks at the Holy Sepulchre in Jerusalem, but in pious appreciation of the one solitary object on which they can unite in peaceful worship."

This historically viewed religious and ethnic co-existence at Sri Pada, as argued elsewhere, began to fade with concurrent emergence of dominant forms of Sinhala Buddhist nationalism in postcolonial Sri Lanka (De Silva, 2005).

However, in general, the totalising diverse religious practices of the natives as 'heathen' or non-Christian under the authoritative knowledge production of three hegemonic colonisers, would not support religious multiplicity at Sri Pada; rather discursive constructions would eventually undermine it. This is the process by which 'Adam's Peak' came to be systematically identified and constituted in European discourses in the first half of the nineteenth century. At the same time, Sri Pada was identified as a most popular pilgrimage site among 'native religious' counterparts of the country

30 The rejection not only came from the orientalists but also from hard line Buddhist reformers like American theosophist Henry Steel Olcott. Dharmapala broke with Olcott in 1904 because Olcott showed disrespect toward the relic of the Buddha's tooth, one of the most sacred sites of the Buddhist pilgrims (Obeyesekere, 1976). 
and apparently became the gaze of the British colonial regime as an important site for physical control ${ }^{31}$.

\section{CONCLUSION}

Nowhere is the process of the production of colonial knowledge more evident than the colonial encounter with the practices of 'exotic' religion. 'Adam's Peak' was created as a way of assimilating the exotic people they were encountering. Such assimilation, as explained, changed historically with changes under different colonial powers. It is quite clear that the formation of western knowledge on Adam's Peak was itself part of the larger colonial production of knowledge of British Ceylon. As one can see, the early nineteenth century production of knowledge of Adam's Peak was largely the work of British military men. However, by the middle of the century, it was largely produced through the Christian colonial administrators who were much more organised as 'positivist historian' under the umbrella of the Royal Asiatic Society. Therefore, the production of knowledge over colonised subjects in Sri Lanka in particular, and South and Southeast Asia in general, should not be limited to one particular colonial power, because 'colonial history' in these regions is much more complex and deeper than what some of the scholars have thought out. As mentioned at the beginning of this article, the failure to grasp the deep 'roots' of colonial knowledge productions that go well beyond the British colonial projects in these historical regions would be crucial in the understanding of the key terms that occured in the nineteenth century such as 'Adam's Peak', 'demonism', 'Buddhism', 'Hinduism' and many more.

\section{ACKNOWLEDGEMENT}

This project on Sri Pada was funded by Wenner-Gren Foundation for Anthropological Research and the final draft of this paper was completed under the British Academy Fellowship to the University of Edinburgh in 2009. The author would like to thank Jonathan Spencer, Rohan Bastin, Charles Halissey, Bob Simpson, Michael Roberts, Kumari Jayawardene and the two anonymous reviewers for their valuable comments. None of them is responsible for the shortcomings that remain.

\section{REFERENCES}

Abeyasinghe, T. (1966) Portuguese rule in Ceylon, Colombo: Lake House, pp: 1594-1612.

Abeysekara, A. (2002) Colors of the robe: religion, identity and difference, University of South Carolina Press.
Almond, P. (1988) The British discovery of Buddhism, Cambridge \& New York: Cambridge University Press.

Arasaratnam, S. (1978) (tran. \& ed.) Francois Valentijn's description of Ceylon, London: The Hakluyt Society.

Bassett, R. H. (1927) Romantic Ceylon: its history, legend and story, London: Cecil Palmer.

Bayly, C. A. (1998) Origins of nationality in South Asia: patriotism and ethical government in the making of modern India, Delhi: Oxford University Press.

Bayly, S. (1999) Caste, society and politics in India from the eighteenth century to the modern age, Cambridge: Cambridge University Press.

Bell, H. C. P. (1916) 'Maha Saman Devalaya and its sannasa', CALR, Vol.II.

Bennet, J. W. (1843) Ceylon and its capabilities: an account of its natural resources, indigenous productions, and commercial facilities, London: W.H. Allen \& Co.

Bond, G. D. (1988) The Buddhist revival in Sri Lanka: religious tradition, reinterpretation and response, Columbia: University of South Carolina Press.

Chakrabarty, D. (2000) Provincializing Europe: postcolonial thought and historical difference, Princeton: Princeton University.

Chatterjee, P. (1993) The nation and its fragments: colonial and postcolonial histories, Princeton: Princeton University Press.

Cohn, B. S. (1985) 'Anthropology and history in 1980's', Journal of Interdisciplinary History, 12, pp: 227-252.

DOI: http://dx.doi.org/10.2307/203026

Cohn, B. S. (1996) Colonialism and its forms of knowledge: the British in India, Princeton: Princeton University Press.

Davy, J. (1821) An account of the interior of Ceylon and of its inhabitants, London (reprinted by Tisara Prakasakayo, Dehiwala, Sri Lanka in 1983).

de Queyroz, F. (1930) The temporal and spiritual conquest of Ceylon, tr. S. G. Perera. Colombo: Government Printer.

De Silva, P. (2002) Past in the present: the problematic of interpreting 'history' in a plural society. Pravada, 10(6), Colombo: Social Scientists’ Association.

De Silva, P. (2005) Sri Pada: diversity and exclusion in a sacred site in Sri Lanka, unpublished Ph.D Thesis, The University of Edinburgh.

31 The author discussed elswhere (de Silva, 2015) the legal technologies that were used to control Sri Pada throughout the 'British colonial regime.' 
De Silva, P. (2007) 'Hindu and Muslim connections to Sri Pada'. In: J. Uyangoda, ed. Religion in context, Colombo: Social Scientists' Association.

De Silva, P. (2013) 'Reordering of post colonial Sri Pada temple in Sri Lanka: Buddhism, state and nationalism', History and Sociology of South Asia, 7(2), pp: 155-176.

DOI: http://dx.doi.org/10.1177/2230807513479041

De Silva, P. (2015) Colonial governmentality: legal and administrative technologies of the governance of Sri Pada temple, In: T. Borchert, ed. Theravada Buddhist communities in colonial Asia, London: Routledge (fourth coming)

Dirks, N. B. (1992) Colonialism and culture, Ann Arbor: University of Michigan Press.

Dirks, N. B. (2001) Caste of mind: colonialism and the making of modern India, Princeton: Princeton University Press.

Foucault, M. (1984) Truth and power. In: Paul Rabinow, ed. The Foucault Reader, New York: Pantheon.

Guha, R. (1982) Subaltern studies: writings on South Asian history and society, Delhi: University of Oxford Press. (Vol. I to VI).

Hallisey, C. (1995) Roads Taken and Not Taken in the Study of Theravada Buddhism, In: Lopex, S. D., ed. Curators of the Buddha: the study of Buddhism under colonialism, Chicago: University of Chicago Press.

Harris, E. J. (1994) The gaze of the colonizer, Colombo: Social Scientists' Association.

Inden, R. (1986) Orientalist constructions of India, Modern Asian Studies, 20(3), pp: 401-466.

DOI: http://dx.doi.org/10.1017/S0026749X00007800

Inden, R. (1990) Imagining India. London: Blackwell.

Jeganathan, P. (1995) Authorizing history, ordering land: the conquest of Anuradhapura, In: P. Jeganathan and Q. Ismail eds, Unmaking the nation, Colombo: Social Scientists' Association.

Jeganathan, P., \& Ismail, Q., (1995) (eds.) Unmaking the nation, Colombo: Social Scientists' Association.

Kemper, S. (1991) The presence of the past: chronicles, politics and culture in Sinhala life, Cornell: Cornell University Press.

Knox, R. (1911) An historical relations of Ceylon together with somewhat concerning several remarkable passages of my life, Glasgow: James Ryan.

Malalgoda, K. (1973) 'The Buddhist-Christian confrontation in Ceylon 1800-1880'. Social Compass, xx (2), pp: 171-200 DOI: http://dx.doi.org/10.1177/003776867302000204
Malalgoda, K. (1976) Buddhism in Sinhalese society 17501900: a study of religious revival and change, London: University of California Press.

Malalgoda, K. (1997) Concepts and confrontations: a case study of agama. In: M. Roberts, ed. Sri Lanka Collective Identities Revisited, Colombo: Marga Publication.

Nissan, E. (1985) The sacred city of Anuradhapura: aspects of Sinhalese Buddhism and nationhood, unpublished $\mathrm{Ph}$. D thesis, University of London.

Nissan, E. (1989) 'History in the making: Anuradhapura and the Sinhala Buddhist nation'. Social Analysis, No 25, Sep.

Obeyesekere, G. (1976) Personal identity and cultural crisis: the case of Anagarika Dharmapala of Sri Lanka, In: Frank Reynolds and Donald Capps, eds. The biographical process: studies in the history and psychology of religion, Paris: Mouton.

Obeyesekere, G. (1995) Buddhism, nationhood, and cultural identity: a question of fundamentals, In: M. E.Marty and R. S. Appleby eds. Fundamentalism comprehended, Chicago: Chicago University Press, pp: 232-44.

Pandy, G. (1990) The construction of communalism in colonial north India, Delhi: Oxford University Press.

Peabody, N. (2001) Cents, sense, census: human inventories in late pre-colonial and early colonial India, Comparative Studies in Society and History, 43(4), pp: 819-850.

Peiris, E. (1972) (ed.) The spiritual conquest of the East: chapters on Meersman, F.A. the introduction of Christianity to Ceylon', Colombo.

Pels, P. (1997) 'The Anthropology of colonialism: culture, history and the emergence of western governmentality', Annual review of anthropology, 26, pp: 163-183.

DOI: http://dx.doi.org/10.1146/annurev.anthro.26.1.163

Ribeiro, J. (1948) History of Ceilao, tr. P. E. Peiris. Colombo: Ceylon Daily News Press.

Roberts, M. (1989) 'A tale of resistence: the story of the arrival of the Portuguese in Sri Lanka', Ethnos, 54, pp: 69-81.

DOI: http://dx.doi.org/10.1080/00141844.1989.9981382

Roberts, M. (2001) 'Submerging the people? Post-orientalism and the construction of communalism', In: George Beremer et al. eds. Explorations in South Asia history. Festschrift for Dietmar Rothermund on the occasion of his 65th birthday, New Delhi:Manohar, pp: 323-331.

Roberts, M. (2003) Sinhala consciousness in the Kandyan Period 1590 to 1815, Colombo: Vijitha Yapa Publication. 
Rogers, D. J. (1994) 'Post-orientalism and the interpretation of pre-modern and modern political identities: the case of Sri Lanka,' Journal of Asian Studies, 53, pp: 10-23.

DOI: http://dx.doi.org/10.2307/2059524

Rogers, D. J. (2004) 'Early British rule and social classification in Lanka', Modern Asian Studies, 38, pp: 625-647. DOI: http://dx.doi.org/10.1017/S0026749X03001136

Said, E. (1978) Orientalism, New York: Pantheon.

Scott, D. (1994a) 'Religion in colonial civil society: Buddhism and modernity in 19th century Sri Lanka'. The Thatched Patio, July/ August, 1-16.

Scott, D. (1994b) Formation of ritual: colonial and anthropological discourses on the Sinhala Yaktovil, London: University of Minnesota Press.

Scott, D. (1999) Refashioning future: criticism after postcoloniality, Princeton: Princeton University Press.

Seneviratne, H. L. (1999) The work of kings: the new Buddhism in Sri Lanka, Chicago: University of Chicago Press.

Skeen, W. (1870) Adam's Peak, legendary, traditional and historic notices of the Samanala and Sri-Pada with a descriptive account of the pilgrim's route from Colombo to the sacred footprint, Colombo: W. H. L. Skeen \& Co.

Spencer, J. (1990a) 'The power of the past.' In: J. Spencer ed. Sri Lanka: history and the roots of conflict, London: Routledge.
Spencer, J. (1990b) 'Tradition and transformation: recent writing on the anthropology of Buddhism in Sri Lanka', Journal of the Anthropological Society of Oxford, $\mathrm{xx}(1,2)$.

Spencer, J. (1997) 'Post-colonialism and the political imagination,' Journal of Royal Anthropological Institute, 3, pp: 1-19.DOI: http://dx.doi.org/10.2307/3034362

Still, J. (1930) The jungle tide, Edinburgh and London: Blackwood \& Sons.

Stirrat, R. L. (1992) Power and religiosity in a post-colonial setting: Sinhala Catholics in contemporary Sri Lanka, Cambridge: Cambridge University Press.

Stokes, E. (1959) The English utilitarians and India, Oxford: Oxford University Press.

Tennent, E. J. (1859) Ceylon: an account of the island, physical, historical and topographical with notices of its natural history, antiquities and productions, London: Longman, Green, Longman.

Van der Veer, P. (1994) Religious nationalism: Hindus and Muslims in India, London: University of California Press.

Wagoner, P. B. (2003) 'Precolonial intellectuals and the production of colonial knowledge', Comparative studies in society and history, 45(4), pp: 783-814.

DOI: http://dx.doi.org/10.1017/S0010417503000355

Walters, J. (1996) The history of Kelaniya, Colombo: Social Scientists' Association. 